\title{
PERJANJIAN BUILD OPERATE AND TRANSFER (BOT) LAPANGAN MERDEKA MEDAN DALAM PANDANGAN HUKUM ADMINSITRASI NEGARA DAN HUKUM BISNIS
}

\author{
Rahmat Ramadhani, Ramlan \\ Fakultas Hukum Universitas Muhammadiyah Sumatera Utara \\ Jl. Kapt. Mukhtar Basri Nomor 3, Medan - Sumatera Utara \\ Email: rahmatramadhani@umsu.ac.id,ramlan@umsu.ac.id
}

\begin{abstract}
Abstrak
Perjanjian BOT adalah perjanjian antara pemerintah dengan investor dalam hal penguasaan dan pemanfaatan asset negara berupa tanah. Penulisan ini menggunakan metode penelitian hukum yuridis normatif (normatif research) dengan spesifikasi penelitian deskriptif analistis yang menggunakan data sekunder. Prosedur pengumpulan datanya adalah berupa dokumentasi catatan atau kutipan, penelusuran literatur hukum, buku-buku dan lainnya yang bertalian dengan identifikasi masalah baik secara cara offline maupun online yang kemudian dianalisa dengan menggunakan pendekatan perundang-undangan melalui metode analisa konten (content analysis method) dengan fokus pada permasalahan tentang bagaimana penerapan prinsip BOT dalam perjanjian kerjasama pembangunan dan pengelolaan Lapangan Merdeka antara Pemko Medan dengan pihak swasta? dan bagaimana pandangan Hukum Administrasi Negara dan Hukum Bisnis terhadap perjanjian BOT dalam pembangunan dan pengelolaan Lapangan Merdeka antara Pemko Medan dengan pihak swasta?. Dari hasil penelitian diketahui bahwa perjanjian kerjasama antara Pemko Medan dengan Pihak Swasta telah menerapkan prinsip BOT dengan memenuhi unsur membangun, mengelola dan menyerahkan hasil pembangunan dan pengelolaan oleh Investor kepada Pemko Medan. Selanjutnya perjanjian BOT dimaksud dipandang dari Hukum Administrasi Negara merupakan perbuatan pejabat adminitrasi Negara yang berdimensi hukum publik dan hukum privat. Sedangkan dalam pandangan Hukum Bisnis perjanjian BOT harus sama-sama menguntungkan kedua belah pihak yang melakukan perjanjian.
\end{abstract}

\section{Kata Kunci: Perjanjian, BOT, Hukum, Adminitrasi, Bisnis}

\section{Abstract}

The BOT agreement is an agreement between the government and investors in terms of mastering and utilizing state assets in the form of land. This writing uses the normative juridical legal research method (normative research) with descriptive analytical research specifications that use secondary data. The procedure for collecting data is in the form of documentation of notes or quotations, search of legal literature, books and others related to the identification of problems both offline and online, which are then analyzed using a legal approach through content analysis method with a focus on the issue of how the application of the BOT principle in the cooperation agreement on development and management of Merdeka Field between Pemko Medan and the private sector? and what is the view of State Administrative Law and Business Law on the BOT agreement in the development and management of Merdeka Field between the Pemko Medan and the private sector?. From the results of the study it is known that the cooperation agreement between Pemko Medan and the Private Party has implemented the BOT principle by fulfilling the elements of building, managing and submitting the results of development and management by the Investor to Pemko Medan. Furthermore, the said BOT 
DEIEGA IATA

Jurnal Ilmu Hukum

FAKULTAS HUKUM UMSU
Perjanjian BOT...(Rahmat Ramadhani, Ramlan)

Volume 4 Nomor 2, Juli-Desember 2019, 255-270

DOI: https://doi.org/10.30596/dll.v4i2.3182

agreement is viewed from the State Administrative Law, an official act of the State administration that has dimensions of public law and private law. Whereas in the view of Business Law the BOT agreement must equally benefit both parties who make the agreement.

\section{Keywords: Agreement, BOT, Law, Administration, Business}

\section{PENDAHULUAN}

Sebagai kota ketiga terbesar di Indonesia, selain menjadi pusat kegiatan perekonomian di wilayah Bagian Barat Indonesia, Kota Medan juga merupakan salah satu pintu bagi arus penumpang serta perdagangan barang dan jasa, baik perdagangan domestik maupun luar negeri (melalui: http://aa-medan.blogspot.co.id/2012/12/profil-kotamedan.html, 2012). Selain sektor industri, Kota Medan juga dikenal sebagai kota kuliner. Banyak suguhan jajanan pangan yang menjadi ciri khas Kota Medan. Berbagai tempat usaha jajanan kuliner kemudian menjamur di Kota Medan sejak beberapa tahun terakhir.

Paradigma pengembangan bisnis kuliner di Kota Medan juga terlihat tidak stagnan pada modifikasi keunggulan rasa dari menu kuliner yang dijajakan. Trend menciptakan 'tempat nongkrong' yang asyik sembari mencicipi hidangan kuliner di tengah suasana malam Kota Medan menjadi peluang bisnis yang menjanjikan. Peluang tersebut telah dibaca oleh Pemerintah Kota Medan (Pemko Medan) sejak lama. Sekitar tahun 2003 Pemko Medan telah berupaya memanfaatkan peluang tersebut dengan menggandeng beberapa pedangan kuliner yang berasala dari kalangan masyarakat Kota Medan dan meghadirkan sebuah pusat jajanan kuliner malam hari bernama Kesawan Square.

Letak Kesawan Square berada di Jalan A. Yani Kota Medan. Pada siang hari jalan ini berfungsi sebagai jalan raya yang berstatus jalan kota tempat lalu lintas kendaraan menuju dan dari pusat Kota Medan. Di jalan tersebut juga terdapat ragam aktivitas perdagangan dan perkantoran pada pagi hingga sore hari, sebab memang di sisi kanan dan kiri jalan dimaksud terdapat toko-toko alat musik dan olah raga serta beberapa perkantoran. Mulai pukul $16 .^{00} \mathrm{WIB}$ hingga pukul $00 .^{00} \mathrm{WIB}$, ruas Jalan A. Yani (mulai dari pesimpangan Jalan Pemuda/Jalan Palang Merah sampai dengan persimpangan Gedung Kantor PT. Londong Sumatera Indonesia) ditutup dan digunakan sebagai lokasi Kesawan Square.

Ide cemerlang Pemko Medan dimaksud membuahkan hasil yang memuaskan. Tingginya antusias masyarakat Kota Medan terhadap keberadaan Kesawan Square ditandai dengan ramainya pengunjung di setiap jam opersionalnya. Tentu keberhasilan ini berefek positif terhadap tergalinya potensi Pendapatan Asli Daerah (PAD) dari sektor pajak dan retribusi daerah. Di samping menciptakan peluang penghasilan bagi masyarakat Kota Medan yang bergabung sebagai pedagang kuliner pada event tersebut.

Melihat berbagai potensi menguntungkan bagi Pemko Kota Medan dari bisnis yang diperoleh dengan adanya wisata kuliner di Kesawan Square tersebut, Pemko Medan selanjutnya menggandeng investor untuk bekerja sama dalam mengulang kesuksesan yang sama. Ikatan kerja sama Pemko Medan dengan pihak investor dalam menggunakan kawasan sisi barat Lapangan Merdeka Medan sebagai lahan tempat usaha kuliner dengan bernama Merdeka Walk 
Jurnal Ilmu Hukum

FAKULTAS HUKUM UMSU
Perjanjian BOT...(Rahmat Ramadhani, Ramlan)

Volume 4 Nomor 2, Juli-Desember 2019, 255-270

DOI: https://doi.org/10.30596/dll.v4i2.3182

adalah berdasarkan perjanjian Build, Operate and Transfer (BOT). Merdeka Walk sendiri hingga saat ini dikenal sebagai salah satu ikon Kota Medan.

Dipilihnya sisi barat Lapangan Merdeka sebagai lokasi pembangunan Merdeka Walk didasarkan pada berbagai alasan Pemko Medan saat itu . Salah satu alasanya menurut Wali Kota Medan saat ini yaitu T.Dzulmi Eldin adalah "bahwa sisi barat Lapangan Merdeka Medan dahulunya hanya dijadikan tempat parkiran taksi gelap dan berbagai kehidupan malam dan juga banyak kenakalan-kenakalan yang tidak bisa dikontrol" (melalui: http://medan.tribunnews.com/2019/02/17/wacana-penutupan-merdeka-walk-pengelola-kamiikut-pemerintah-tapi-hormati-kontrak?page=all, 2019). Di sisi lain, pemanfaatan sisi timur Lapangan Merdeka tetap dipertahankan sebagai tempat untuk mengambangkan kreasi, seni dan budaya serta sarana olah raga bagi masyarakat Kota Medan.

Penggunaan dan pemanfaatan sisi barat Lapangan Merdeka Medan sebagai tempat usaha bernama Merdeka Walk, belakangan ini memunculkan ragam wacana. Salah satunya adalah wacana yang dilontarkan oleh Gubernur Sumatera Utara (melalui: http://medan.tribunnews.com/2019/02/17/wacana-penutupan-merdeka-walk-pengelola-kamiikut-pemerintah-tapi-hormati-kontrak?page=all, 2019). tentang penutupan Merdeka Walk dan megembalikan fungsi lapangan merdeka sebagaimana mestinya. Tentu aspek histori dan fungsi utama keberadaan lapangan merdeka yang menjadi latar belakang pemikiran munculnya wacana penutupan Merdeka Walk tersebut.

Lapangan Merdeka Medan adalah salah satu asset Pemko Medan yang merupakan Barang Milik Daerah (BMD) berupa tanah. Dalam penggunaan dan pemanfaat Lapangan Merdeka baik sebagian maupun seluruhnya sebagai tempat usaha yang dibangun dan dikelola oleh pihak swasta dengan sistem apapun termasuk BOT haruslah didudukan dalam berbagai pandangan hukum. Maka oleh karenanya, penting untuk dianalisis tentang keberadaan perjanjian BOT terhadap penggunaan Lapangan Merdeka Medan dalam pandangan Hukum Administrasi Negara dan Hukum Bisnis.

Fokus permasalahan dalam penulisan ini adalah; Pertama, bagaimana penerapan prinsip BOT dalam perjanjian kerjasama pembangunan dan pengelolaan Lapangan Merdeka antara Pemko Medan dengan Pihak Swasta? Dan Kedua, bagaimana pandangan Hukum Administrasi Negara dan Hukum Bisnis terhadap perjanjian BOT dalam pembangunan dan pengelolaan Lapangan Merdeka antara Pemko Medan dengan Pihak Swasta? Harapannya tulisan ini dapat bermanfaat baik secara teori maupun praktis dalam mengkaji perjanjian BOT terhadap penggunaan Lapangan Merdeka Medan tertutama dalam pandangan Hukum Administrasi Negara dan Hukum Bisnis.

\section{METODE PENELITIAN}

Penulisan ini menggunakan metode penelitian hukum yuridis normatif (normatif research). Sesuai jenis dan sifat penelitiannya, maka sumber data yang digunakan dalam penulisan ini adalah data skunder yang terdiri dari bahan hukum primer berupa; peraturan perundang-undangan yang berlatian dengan tema pembahasan. Bahan hukum sekunder dalam 
DELEGA LATA

Jurnal Ilmu Hukum

FAKULTAS HUKUM UMSU
Perjanjian BOT...(Rahmat Ramadhani, Ramlan)

Volume 4 Nomor 2, Juli-Desember 2019, 255-270

DOI: https://doi.org/10.30596/dll.v4i2.3182

penelitian ini terdiri dari buku-buku, jurnal ilmiah, makalah dan artikel ilmiah yang dapat memberi penjelasan tentang bahan hukum primer. Sedangkan bahan hukum tersierberupa Kamus Besar Bahasa Indonesia (KBBI) dan lain sebagainya dalam menemukan defenisi dari istilah-istilah dalam membahas tentang BOT.

Prosedur yang digunakan untuk mengumpulkan data dalam penilitian ini berupa dokumentasi berupa catatan atau kutipan, penelusuran literatur hukum, buku-buku dan lainnya yang bertalian dengan identifikasi masalah dalam penilitian dimaksud dengan cara offline maupun online. Pendekatan yang digunakan dalam penelitian ini adalah menggunakan pendekatan perundang-undangan. Maka analisa bahan hukum dilakukan adalah dengan menggunakan metode analisa konten (centent analysis method) yang dilakukan dengan menguraikan materi peristiwa hukum atau produk hukum secara rinci guna memudahkan interpretasi dalam pembahasan.

\section{PEMBAHASAN}

Penerapan Prinsip BOT Dalam Perjanjian Kerjasama Pembangunan Dan Pengelolaan Lapangan Merdeka Antara Pemko Medan dengan Pihak Swasta

\section{Pengertian dan Pengaturan Hukum BOT di Indonesia}

Pengertian perjanjian Build Operate and Transfer (BOT) dalam tata hukum Indonesia diartikan sebagai perjanjian Bangun Guna Serah (BGS). Rujukan hukum yang mengatur pertama kali tentang Perjanjian BGS (selanjutnya difahami sebagai BOT) tertuang dalam Keputusan Menteri Keuangan Republik Indonesia (Kep. Menkeu RI) Nomor: 248/KMK.04/1995 tanggal 2 Juni 1995 tentang Perlakuan Pajak Penghasilan Terhadap PihakPihak yang Melakukan Kerjasama dalam Bentuk Perjanjian Bangun Guna Serah. Pengertian BGS menurut Kep. Menkeu RI tersebut yaitu;

Bentuk perjanjian kerjasama yang dilakukan antara pemegang hak atas tanah dengan investor, yang menyatakan bahwa pemegang hak atas tanah memberikan hak kepada investor untuk mendirikan bangunan selama masa perjanjian bangun guna serah, dan mengalihkan kepemilikan bangunan tersebut kepada pemegang hak atas tanah setelah masa guna serah berakhir.

Pengertian BGS juga dapat ditemukan dalam Peraturan Pemerintah Nomor 6 Tahun 2006 Tentang Pengelolaan Barang Milik Negara, sebagaimana telah diubah dengan Peraturan Pemerintah Nomor 38 Tahun 2008 tentang Perubahan Peraturan Pemerintah Nomor 6 Tahun 2006 Tentang Pengelolaan Barang Milik Negara. Pasal 1 angka 2 peraturan pemerintah dimaksud menguraikan bahwa;

Bangun Guna Serah (BGS) adalah pemanfaatan tanah milik negara/daerah berupa tanah oleh pihak lain dengan cara mendirikan bangunan dan/atau sarana berikut fasilitasnya, kemudian didayagunakan oleh pihak lain tersebut dalam jangka waktu tertentu yang telah disepakati, untuk selanjutnya diserahkan kembali tanah beserta bangunannya dan/atau sarana berikut fasilitasnya setelah berakhirnya jangka waktu. 
Jurnal Ilmu Hukum

FAKULTAS HUKUM UMSU
Perjanjian BOT...(Rahmat Ramadhani, Ramlan)

Volume 4 Nomor 2, Juli-Desember 2019, 255-270

DOI: https://doi.org/10.30596/dll.v4i2.3182

Defenisi lain juga dapat dilihat di dalam Peraturan Menteri Dalam Negeri Republik Indonesia Nomor 19 tahun 2016 tentang Pedoman Pengelolaan Barang Milik Daerah Bab 1 butir 36 dan 37, sebagai berikut:

Bab 1 butir 36:

BGS adalah Pemanfaatan barang milik daerah berupa tanah oleh pihak lain dengan cara mendirikan bangunan dan/atau sarana berikut fasilitasnya, kemudian didayagunakan oleh pihak lain tersebut dalam jangka waktu tertentu yang telah disepakati, untuk selanjutnya diserahkan kembali tanah beserta bangunan dan/atau sarana berikut fasilitasnya setelah berakhirnya jangka waktu.

Bab 1 butir 37:

BGS adalah pemanfaatan barang milik daerah berupa tanah oleh pihak lain dengan cara mendirikan bangunan dan/atau sarana berikut fasilitasnya, dan setelah selesai pembangunannya diserahkan untuk didayagunakan oleh pihak lain tersebut dalam jangka waktu tertentu yang disepakati.

Peraturan Menteri Negara Badan Usaha Milik Negara Nomor PER-06/MBU/2011 tentang Pedoman Pendayagunaan Aktiva Tetap Badan Usaha Milik Negara, merumuskan pengertian BGS sebagaimana tercantum pada Pasal 1 angka 9 yaitu;

Bangun Guna Serah adalah kerjasama pendayagunaan aktiva tetap berupa tanah milik BUMN oleh pihak lain dengan cara mendirikan bangunan dan/atau sarana berikut fasilitasnya, kemudian didayagunakan oleh pihak lain tersebut dalam jangka waktu tertentu yang disepakati, untuk selanjutnya tanah beserta bangunan dan/atau sarana berikut fasilitasnya diserahkan kepada BUMN setelah berakhirnya jangka waktu.

Selain regulasi yang memberikan deefenisi sekaligus mengamini keberlakukan Perjanjian BOT dalam sistem hukum di Indonesia sebagaimana diuraikan di atas, masih terdapat beberapa peraturan perundang-undangan lainnya yang mengakui keberadaan perjanjian BOT dimaksud, yaitu sebagai berikut: (melalui: www.bandarlampung. bpk.go.id/wp.../tulisan_hukum_BOT_Pwk_Lampung_rev.pdf, 2019).

a. Peraturan Pemerintah Nomor 27 Tahun 2014 tentang tentang Pengelolaan Barang Milik Negara, terurai dalam pasal-pasal sebagai berikut;

1)Pasal 1 angka 14 menyatakan bahwa bangun guna serah adalah pemanfaatan barang milik negara/daerah berupa tanah oleh pihak lain dengan cara mendirikan bangunan dan/atau sarana berikut fasilitasnya, kemudian didayagunakan oleh pihak lain tersebut dalam jangka waktu tertentu yang telah disepakati, untuk selanjutnya diserahkan kembali tanah beserta bangunan dan/atau sarana berikut fasilitasnya setelah berakhirnya jangka waktu.

2)Pasal 1 angka 15 menyatakan bahwa bangun serah guna adalah pemanfaatan barang milik negara/daerah berupa tanah oleh pihak lain dengan cara mendirikan bangunan dan/atau sarana berikut fasilitasnya, dan setelah selesai pembangunannya diserahkan untuk didayagunakan oleh pihak lain tersebut dalam jangka waktu tertentu yang disepakati. 
Jurnal Ilmu Hukum

FAKULTAS HUKUM UMSU
Perjanjian BOT...(Rahmat Ramadhani, Ramlan)

Volume 4 Nomor 2, Juli-Desember 2019, 255-270

DOI: https://doi.org/10.30596/dll.v4i2.3182

3)Pasal 27 menyatakan bahwa bentuk-bentuk pemanfaatan barang milik negara/daerah berupa sewa, pinjam pakai, kerjasama pemanfaatan, bangun guna serah dan bangun serah guna, atau kerja sama penyediaan infrastruktur.

b. Undang-Undang Nomor 23 Tahun 2014 tentang Pemerintahan Daerah sebagaimana telah diubah terakhir dengan Undang-Undang Nomor 9 Tahun 2015, termaktub dalam pasal-pasal sebagai berikut;

1) Pasal 363 ayat 1 menyatakan bahwa dalam rangka meningkatkan kesejahteraan rakyat, daerah dapat mengadakan kerjasama yang didasarkan pada pertimbangan efisiensi dan ekektivitas pelayanan publik serta saling menguntungkan.

2) Pasal 363 ayat 2 menyatakan bahwa kerjasama sebagaimana dimaksud pada ayat 1 dapat dilakukan oleh daerah dengan:

a) daerah lain;

b) pihak ketiga; dan/atau

c) lembaga atau pemerintah daerah di luar negeri sesuai dengan ketentuan peraturan perundang-undangan.

3) Pasal 366 ayat 1 menyatakan bahwa kerjasama daerah dengan pihak ketiga sebagaimana dimaksud dalam Pasal 363 ayat 2 huruf b meliputi:

a) kerjasama dalam penyediaan pelayanan publik;

b) kerjasama dalam pengelolaan aset untuk meningkatkan nilai tambah yang memberikan pendapatan bagi daerah;

c) kerjasama investasi; dan kerjasama lainnya yang tidak bertentangan dengan ketentuan peraturan perundang-undangan.

4) Pasal 366 ayat 2 menyatakan bahwa kerjasama daerah dengan pihak ketiga dituangkan dalam kontrak kerja sama yang paling sedikit mengatur:

a) hak dan kewajiban para pihak;

b) jangka waktu kerjasama;

c) penyelesaian perselisihan; dan

d) sanksi bagi pihak yang tidak memenuhi perjanjian.

5) Pasal 366 ayat 3 menyatakan bahwa kerjasama daerah dengan pihak ketiga sebagaimana dimaksud pada ayat 1 harus didahului dengan studi kelayakan yang dilakukan oleh para pihak yang melakukan kerjasama.

Meskipun BOT tidak diatur secara khusus dalam pengaturan hukum di Indonesia namun beberapa regulasi yang mengatur tentang BOT sebagaimana telah diuraikan di atas layak menjadi pedoman dalam pelaksanaan BOT. Termasuk penegasan Pasal 27 Peraturan Pemerintah Nomor 27 Tahun 2014 sebagai aturan pelaksanaan dari ketentuan Undang-Undang Nomor 1 Tahun 2004 tentang Perbendaharaan Negara (melalui: www.bandarlampung. bpk.go.id/wp.../tulisan_hukum_BOT_Pwk_Lampung_rev.pdf, 2019).

Merujuk pada ketentuan yang telah digariskan oleh beberapa peraturan perundangundangan di atas, maka dapat difahami bahwa perjanjian BOT secara normatif tidak diatur secara khusus dalam pengaturan perundang-undangan yang berlaku di Indonesia, bahkan penggunaan istilah BOT pun juga masih beragam, ada yang masih menggunakan istilah aslinya untuk kata BOT dan ada yang sudah diterjemahkan dengan BGS (Bangun Guna Serah) (Irawan Soerodjo, 2016, h. 56). Singkatnya, penggunaan istilah BOT adalah sama dengan istilah BGS, maka oleh karenanya dalam setiap pembahasan perjanjian BOT sama artinya dengan sedang 
DELEGA LATA

Jurnal Ilmu Hukum

FAKULTAS HUKUM UMSU
Perjanjian BOT...(Rahmat Ramadhani, Ramlan)

Volume 4 Nomor 2, Juli-Desember 2019, 255-270

DOI: https://doi.org/10.30596/dll.v4i2.3182

membahas tentang perjanjian BGS, demikian sebaliknya.

Pengaturan hukum terkait dengan perjanjian BOT di Indonesia diatur secara parsial dalam beberapa peraturan perundang-undangan, yaitu sebagai berikut;

1) Undang-Undang Nomor 23 Tahun 2014 tentang Pemerintahan Daerah sebagaimana telah diubah terakhir dengan Undang-Undang Nomor 9 Tahun 2015 tentang Perubahan UndangUndang Nomor 23 Tahun 2014 tentang Pemerintahan Daerah;

2) Pemerintah Republik Indonesia No. 6 Tahun 2006 Tentang Pengelolaan Barang Milik Negara/Daerah dan Peraturan Pemerintah Republik Indonesia No. 38 Tahun 2008 (PP No. 38 Tahun 2008) Tentang Perubahan atas Peraturan Pemerintah Republik Indonesia No. 6 tahun 2006 Tentang Pengelolaan Barang Milik Negara/Daerah;

3) Peraturan Pemerintah Nomor 27 Tahun 2014 Tentang Pengelolaan Barang Milik Negara atau Daerah;

4) Peraturan Pemerintah Nomor 36 Tahun 2005 tentang Peraturan Pelaksanaan UU Nomor 28 Tahun 2002 tentang Bangunan Gedung;

5) Peraturan Menteri Dalam Negeri Republik Indonesia Nomor 17 Tahun 2007 tentang Pedoman Teknis Pengelolaan Barang Milik Daerah;

6) Peraturan Menteri Dalam Negeri Nomor 19 Tahun 2016 tentang pengelolaan barang milik daerah;

7) Keputusan Presiden RI Nomor 7 Tahun 1998 tentang Kerjasama Pemerintah Dan Badan Usaha Swasta Dalam Pembangunan dan atau Pengelolaan Infrastruktur.

\section{Karakteristik dan Prinsip BOT}

Terdapat beberapa karakertistik yang mencolok dari Build, Operate and Transfer (BOT) antara lain; Pertama, BOT sebagai sebuah perjanjian yang mengikat antara dua pihak, dimana pihak yang satu menyerahkan penguasaan tanah miliknya untuk diatasnya didirikan suatu bangunan yang bersifat komersial oleh pihak kedua (investor), dan pihak kedua berhak mengoperasikan bangunan komersial tersebut dengan memberikan fee tertentu kepada pemilik tanah untuk jangka waktu tertentu, dan menyerahkah kepada pemilik tanah setelah jangka waktu tertentu tersebut habis (Siti Ummu Adillah dalam Rahmat Ramadhani, 2018, h. 27). BOT memiliki masa konsesi yaitu masa bagi pihak swasta untuk mengoperasikan proyek selama beberapa tahun (misalnya selama 20 tahun), selama waktu tersebut dapat memungut hasil atau imbalan jasa karena membangun proyek tersebut (Ima Oktorina dalam Cut Zalikha, 2019, h. 28).

Kedua, dari karakter yang terlihat dari jenis perjanjiannya. Bahwa perjanjian BOT pada dasarnya tidak dikenal atau tidak ada namanya dalam Kitab Undang-Undang Hukum Perdata (KUHPer), sebab munculnya perjanjian BOT secara umum dilatarbelakangi oleh adanya tuntutan kebutuhan masyarakat (Irawan Soerodjo, 2016, h. 43). Bentuk Perjanjian tidak bernama tersebut timbul karena adanya penerapan asas Kebebasan Berkontrak sebagaimana ketentuan pasal 1338 ayat 1 KUHPerdata, sehingga para Pihak dapat membuat bentuk Perjanjian yang dikehendakinya (Rachmatia Adonara Korebima, 2018, h. 101). Berdasarkan 
Jurnal Ilmu Hukum

FAKULTAS HUKUM UMSU
Perjanjian BOT...(Rahmat Ramadhani, Ramlan)

Volume 4 Nomor 2, Juli-Desember 2019, 255-270

DOI: https://doi.org/10.30596/dll.v4i2.3182

asas kebebasan berkontrak yang melahirkan perjanjian tidak bernama (onebenoemde overeenkomst) tersebut, kemudian perjanjian BOT tidak diatur secara khusus dalam undangundang, tetapi tumbuh dan berkembang dalam kegiatan ekonomi Indonesia (Anita Kamilah, 2013, h. 129).

Ketiga, Karakteristik BOT selanjutnya adalah dari terletak pada unsur kata BOT itu sendiri yaitu; yaitu Build, Operate and Transfer (membangun, mengoperasikan dan menyerahkan kembali bangunan). Budi Santoso merumuskan unsur-unsur karakternya sebagai berikut; (Budi Santoso, 2008, h. 17).

1) Kewajiban investor adalah menyiapkan pendanaan dan melaksanakan pembangunan atau mendirikan bangunan lengkap dengan saran dan fasilitas berikut perizinan yang diperlukan agar proyek bangunan tersebut dapat dioperasikan.

2) Selanjutnya investor berhak untuk mengoperasikan bangunan proyek yang sudah jadi beserta sarana dan fasilitasnya untuk jangka waktu tertentu sekaligus mengambil manfaat ekonomis dari bangunan proyek tersebut dengan memasarkan kepada pihak ketiga sesuai peruntukkan bangunannya sejak awal (misalnya pusat perbelanjaan, terminal dan lainnya). Teramasuk pula share benefit atas pengeloalaan bangunan dimaksud sesuai kesepakatan yang tertuang dalam perjanjian BOT.

3) Kewajiban investor berikutnya adalah setelah masa pengoperasian atau penggunaannya berakhir, investor wajib menyerahkan bangunan beserta sarana dan fasilitasnya kepada pemilik lahan dalam keadaaan layak guna atau layak pakai. Penyerahan dilakukan tanpa ada syarat atau kewajiban dari pemilik tanah/lahan untuk membayar nilai bangunan. Apabila dalam proses penyerahan tersebut diperlukan biaya, maka biaya tersebut menjadi tanggungan investor atau sesuai dengan kesepakatan dengan pemilik lahan yang dituangkan dalam perjanjian BOT.

Berdasarkan karakter sebagaimana disebutkan di atas maka unsur-unsur perjanjian BOT meliputi: (Ima Oktorina dalam Cut Zalikha, 2019, h. 53).

1) Investor (penyandang dana)

2) Tanah

3) Bangunan komersial

4) Jangka waktu operasional

5) Penyerahan (transfer)

Dalam kaitan objek perjanjiannya adalah hak atas tanah dan bangunan, maka konsep perjanjian BOT merupakan salah satu bentuk modifikasi penggunaan dan pemanfaatan hak atas tanah dengan adanya pendirian bangunan di atas tanah hak milik orang lain sebagai sebuah produk politik hukum pertanahan Indonesia yang menganut asas pemisahan horizontal, dimana membuka peluang terciptanya kepemilikan yang berbeda antara tanah dan bangunannya atau bagian yang terdapat pada permukaan tanah dimaksud (Siti Ummu Adillah dalam Rahmat Ramadhani, 2018, h. 21).

Di sisi lain juga harus diperhatikan bahwa Penguasaan, pemilikan dan pemanfaatan hak atas tanah pada dasarnya tidak hanya terbatas kepada hubungan individualistik, melainkan juga kelompok (komunal) yang didasarkan pada suatu ikatan hukum adat antara orang dengan tanah. 
Jurnal Ilmu Hukum

FAKULTAS HUKUM UMSU
Perjanjian BOT...(Rahmat Ramadhani, Ramlan)

Volume 4 Nomor 2, Juli-Desember 2019, 255-270

DOI: https://doi.org/10.30596/dll.v4i2.3182

Bahkan hukum adat menjadi salah satu ruh penyemangat pembentukan Undang-Undang Nomor 5 Tahun 1960 tentang Ketentuan Pokok-Pokok Agraria (UUPA) yang kedudukannya menggantikan cengkraman domein verklaring dengan pengakuan hak ulayat masyarakat hukum adat atas tanah sebagaimana terurai dalam Pasal 3 UUPA (Rahmat Ramadhani, 2019, h. 98).

Hak atas tanah sebagai objek BOT sebagaimana dimaksud di atas berdasarkan Pasal 223 ayat 1 Peraturan menteri Dalam Negeri No 19 Tahun 2016 tentang Pedoman Pengelolaan Barang Milik Daerah, meliputi;

1) Barang Milik daerah berupa Tanah yang berada pada Pengelola barang

2) Barang milik daerah berupa tanah yang berada pada pengguna barang

Sedangkan status hak atas yang dapat dijadikan objek perjanjian BOT berdasarkan ketentuan UUPA adalah:

1) Hak Milik

2) Hak Guna Bangunan

3) Hak Pakai

4) Hak Pengelolaan

Lebih lanjut, BOT sebagai sebuah prinsip dalam suatu perjanjian pada dasarnya terjadi apabila: (Ima Oktorina dalam Cut Zalikha, 2019, h. 53)

1) Ada pemilik tanah atau pihak yang menguasai tanah, ingin membangun suatu bangunan komersial di atas tanahnya tetapi tidak mempunyai biaya, dan ada investor yang bersedia membiayai pembangunan tersebut.

2) Ada investor yang ingin membangun suatu bangunan komersial tetapi tidak mempunyai tanah yang tepat untuk berdirinya bangunan komersial tersebut, dan ada pemilik tanah yang bersedia menyerahkan tanahnya untuk tempat berdirinya bangunan komersial tersebut.

3) Investor membangun suatu bangunan komersial di atas tanah milik pihak lain, dan setelah pembangunan selesai investor berhak mengoperasionalkannya untuk jangka waktu tertentu. Selama jangka waktu operasional, pihak pemilik tanah berhak atas fee tertentu.

4) Setelah jangka waktu operasional berakhir, investor wajib mengembalikan tanah kepada pemiliknya beserta bangunan komersial di atasnya. (Pasal 62 Peraturan Pemerintah Republik Indonesia Nomor 36 Tahun 2005 tentang peraturan pelaksanaan Undang-Undang Nomor 28 Tahun 2002 tentang Bangunan Gedung)

\section{Penerapan Prinsip BOT dalam Perjanjian Kerjasama Pembangunan dan Pengelolaan Lapangan Merdeka Medan}

Pembangunan dan pengelolaan Lapangan Merdeka Medan oleh pihak swasta selaku investor didasarkan pada Perjanjian Kerjasama Nomor: 511.3/11297, Nomor: 007/OIM/VII/2004 Tanggal 23 Juli 2004 antara Pemerintah Kota Medan dengan PT. Orange Indonesia Mandri (PT. OIM)tentang Pembangunan dan Penglolaan Lokasi Sisi Barat Lapangan Merdeka Medan (Ima Oktorina dalam Cut Zalikha, 2019, h. 53). Pembangunan dan pengelolaan sisi barat Lapangan Merdeka Medan adalah sebagai tempat usaha dan pusat bisnis kuliner di tengah Kota Medan yang diberi nama Medeka Walk. 
Jurnal Ilmu Hukum

FAKULTAS HUKUM UMSU
Perjanjian BOT...(Rahmat Ramadhani, Ramlan)

Volume 4 Nomor 2, Juli-Desember 2019, 255-270

DOI: https://doi.org/10.30596/dll.v4i2.3182

Perjanjian antara Pemko Medan dengan PT. Orange Indonesia Mandiri sebagaimana tertulis dalam perjanjian tersebut di atas pada dasarnya telah menerapkan prinsip BOT, dimana unsur-unsurnya relevan dengan yang diuraikan oleh Andjar Pachta Wirana (Andjar Pachta Wirana, 1994, h. 21) sebagai berikut:

Pertama; Adanya para pihak, yaitu investor yang menyediakan dana untuk membangun yaitu PT. OIM, dan pihak pemilik tanah/lahan, yaitu Pemko Medan selaku pemegang hak eksklusif atau penguasa lahan yang terlerak di sisi barat Lapangan Merdeka Medan. Kriteria investor (PT. OIM) untuk menjalin perjanjian kerjasama BOT sesuai dengan ketentuan bahwa untuk menjadi mitra kerjasama perusahaan harus memiliki kemampuan untuk mengelola dan membangun yang baik, serta sehat (Ima Oktorina dalam Cut Zalikha, 2019, h. 53).

Kedua; adanya objek yang diperjanjikan yaitu lahan atau tanah dan bangunan yang dibangun di atas tanah/lahan tersebut. Berdasarkan isi perjanjian antara Pemko Medan dengan PT. OIM diketahui bahwa lokasi lahan yang menjadi objek perjanjian adalah sisi barat Lapangan Merdeka Medan, yaitu terletak di sisi Jalan Bukit Barisan sampai dengan batas Kantor Pembantu Dinas Pertamanan Kota Medan termasuk tambahan 1,5 M (satu koma lima meter) dari batas pagar panjang sisi barat Lapangan Merdeka Medan (Ima Oktorina dalam Cut Zalikha, 2019, h. 53). Status tanah tersebut adalah Barang Milik daerah berupa Tanah yang berada pada Pengelola barang sebagaimana ditentukan dalam Pasal 223 ayat 1 Peraturan menteri Dalam Negeri No 19 Tahun 2016 tentang Pedoman Pengelolaan Barang Milik Daerah.

Ketiga; Investor diberikan hak untuk mengelola atau mengoprasikan dengan pola bagi hasil keuntungan. Berdasarkan perjanjian kerjasama antara Pemko Medan dengan PT. OIM sebagaimana disebutkan di atas, terurai jelas hak dan kewajiban masing-masing pihak. Salah satunya adalah hak PT. OIM mengelola dan mengopersikan Merdeka Walk dengan segala fasilitasnya sebagai hasil pembangunan sisi barat Lapangan Merdeka Medan. Pola bagi hasil yang ditentukan juga tentunya berguna untuk meningkatkan PAD, sekaligus memberdayakan aset yang ada agar lebih berdaya guna, dan meningkatkan perekonomian masyarakat (Ima Oktorina dalam Cut Zalikha, 2019, h. 53).

Keempat; Setelah jangka waktu berakhir, investor mengembalikan tanah beserta bangunan dan segala fasilitasnya kepada pemilik lahan/tanah. Ketentuan terkait dengan kewajiban PT. OIM untuk merawat dan mengembalikan tanah serta menyerahkan bangunan yang dibangunnya dalam kondisi layak pakai juga dituangkan dalam perjanjian kerjasama antara Pemko Medan dengan PT.OIM sebagaimana tersebut di atas. Jangka waktu yang dituangkan dalam perjanjian tersebut adalah 20 (dua puluh) tahun sejak ditandatanganinya surat perjanjian (Ima Oktorina dalam Cut Zalikha, 2019, h. 53).

\section{Pandangan Hukum Administrasi Negara Dan Hukum Bisnis Terhadap Perjanjian BOT Dalam Pembangunan Dan Pengelolaan Lapangan Merdeka Antara Pemko Medan Dengan Pihak Swasta.}

Karakter perjanjian antara Pemko Medan dengan PT. OIM dalam hal Pembangunan dan Pengelolaan Sisi Barat Lapangan Merdeka Medan sebagai tempat usaha yang bernama Merdeka Walk telah nyata dan terang menerapkan prinsip BOT. Pada dasarnya prinsip dalam 
DELEGA LATA

Jurnal Ilmu Hukum

FAKULTAS HUKUM UMSU
Perjanjian BOT...(Rahmat Ramadhani, Ramlan)

Volume 4 Nomor 2, Juli-Desember 2019, 255-270

DOI: https://doi.org/10.30596/dll.v4i2.3182

BOT merupakan perjanjian yang melibatkan pemerintah dengan investor namun akan memberikan manfaat kepada pihak ketiga yaitu masyarakat. Dengan adanya kemamfaatan bagi masyarakat sebagai variabel penting yang harus diperhatikan kedua belah pihak dalam pelaksanaan perjanjian maka dalam perjanjian BOT prinsip pertanggungjawaban yang lebih cocok untuk diterapkan adalah prinsip tanggung jawab berdasarkan unsur kesalahan (Mercy $\mathrm{M}$. M. Setlight, dkk, 2013, h. 146).

Selain meliputi aspek hukum Perdata dan aspek Hukum Pertanahan, penerapan prinsip BOT pada suatu perjanjian kerjasama yang melibatkan pemerintah dengan pihak swasta juga erat kaitnya dengan aspek Hukum Adminitrasi Negara dan Hukum Bisnis.

\section{Pandangan Hukum Administrasi Negara}

Dalam pandagan Hukum Administrasi Negara, maka prinsip BOT dalam yang diterapkan dalam suatu perjanjian kerjasama antara pemerintah dengan pihak swasta sangat berkaitan erat dengan pengaturan yang mengatur tentang barang milik negara/daerah, karena pada umumnya objek perjanjian BOT adalah kekayaan negara yang harus dipertanggung jawabkan dalam pengelolaannya (Rachmatia Adonara Korebima, 2018, h. 102). Selain itu, perjanjian BOT sebagai bentuk perjanjian yang melibatkan pemerintah dalam hal ini pemerintah daerah sebagai salah satu pihak menyebabkan timbulnya percampuran antara hukum publik dan hukum privat dalam bentuk sauatu perjanjian. Kedudukan pemerintah sebagai kontraktan menyebabkan kekhasan dalam perjanjian BOT karena terdapat unsur hukum publik dalam perjanjian dimaksud di samping unsur hukum privat yang terkadung di dalamnya (Mercy M. M. Setlight, dkk., 2013 h, 145).

Dalam padangan Hukum Administrasi Negara, perjanjian kerjasama antara Pemko Medan dengan pihak investor dalam pembangunan dan pengelolaan Lapangan Merdeka Medan dengan pola BOT yang didalamnya melibatkan Pemko Medan sebagai kontraktan masuk ke dalam ranah hukum privat. Sebab hubungan hukum yang terbentuk dari adanya perjanjian tersebut merupakan hubungan hukum dalam ranah perdata. Walaupun di dalam perjanjian kerjasama tersebut kedudukan Pemko Medan sebagai kontraktan juga berlaku syarat-syarat khusus hukum publik terkait dengan kepentingan umum warga Kota Medan terhadap keberadaan dan fungsi Lapangan Merdeka Medan.

Oleh karenanya keabsahan kontrak yang tertuang dalam perjanjian kerjasama antara Pemko Medan dengan PT. OIM dalam hal Penmbangunan dan Pengelolaan Sisi Barat Lapangan Merdeka harus pula diukur dengan Pasal 1320 KUHPer sebagai aturan umum yang menentukan syarat sahnya suatu perjanjian. Karena kontrak tersebut bertalian erat yurisdiksi, bukan dalam lingkup peradilan tata usaha negara, melainkan peradilan umum sebagai konsekuensi dari tindakan pemerintahan yang dilakukan oleh badan atau pejabat tata usaha negara selaku pelaku hukum keperdataan (civil actor) yang melakukan perbuatan hukum keperdataan (Abdul Halim Barkatullah, 2019).

Tindakan Walikota Medan pada saat penandatangan kontrak perjanjian dengan PT OIM sebagaimana dimaksud di atas merupakan tindakan pejabat tata usaha negara mewakili 
DE LEGA LATA

Jurnal Ilmu Hukum

FAKULTAS HUKUM UMSU
Perjanjian BOT...(Rahmat Ramadhani, Ramlan)

Volume 4 Nomor 2, Juli-Desember 2019, 255-270

DOI: https://doi.org/10.30596/dll.v4i2.3182

pemerintah adalah merupakan tindakan keperdataan. Maka perjanjian terebut harus tunduk pada aturan yang berlaku pada ranah hukum privat (perdata). Termasuk pula perbuatanperbuatan yang mendahului sebelum diadakannya kontrak perjanjian tersebut yang dituangkan dalam suatu keputusan (kebijakan) maka keputusan yang dimaksud bukan merupakan keputusan tata usaha negara yang menjadi kompetensi pengadilan tata usaha negara. Sebab halhal yang menyangkut pembentukan, pelaksanaan, perubahan, dan atau pemutusan perjanjian, sekalipun tertuang dalam bentuk keputusan harus dinilai sebagai perbuatan hukum keperdataan. Keputusan yang demikian ini menurut teori melebur dipahami sebagai keputusan yang melebur ke dalam tindakan keperdataan (TIM JDIH BPK Perwakilan Lampung, 2019).

Teori melebur dapat dilihat dan dianut oleh Pasal 2 huruf a Undang-Undang Nomor 5 Tahun 1986 tentang Peradilan Tata Usaha Negara sebagaimana telah diubah terakhir dengan Undang-Undang Nomor 51 Tahun 2009 yang menyatakan bahwa keputusan tata usaha negara yang merupakan perbuatan hukum perdata tidak termasuk dalam pengertian Keputusan Tata Usaha Negara. Jadi, aturan dan prinsip hukum dalam hukum perikatan yang tertuang dalam Buku III KUHPer dengan demikian berlaku bagi kontrak pemerintah di Indonesia, baik yang bernama maupun yang tidak bernama (TIM JDIH BPK Perwakilan Lampung, 2019).

Hal penting yang harus diperhatikan dalam perjanjian kerjasama dalam Pola BOT antara pemerintah dengan investor dalam lingkup tanggung jawab hukum adminitrasi bagi pejabat publik adalah tanggung jawab hukum pidana akibat tindak pidana korupsi yang merugikan negara dalam pelaksanaan perjanjian. Hal ini tidak akan ditemukan dalam perjanjian privat murni. Penggunaan kekayaan negara dalam perjanjian BOT merupakan dasar bagi penggunaan instrumen hukum tindak pidana korupsi dalam pelaksanaan perjanjian dimaksud (Mercy M. M. Setlight, dkk, 2013, h. 147).

\section{Pandangan Hukum Bisnis}

Dalam Pandangan Hukum Bisnis, perjanjian BOT didasarkan pada konsep perjanjian yang saling menguntungkan antara kedua belah pihak. Kedudukan saling menguntungkan juga tersirat dan tersurat di dalam pejanjian kerjasama antara Pemko Medan dengan PT. OIM terkait Pembangunan dan Pengelolaan Sisi Barat Lapangan Merdeka sebagai tempat usaha. Keuntungan yang diperoleh bagi Pemko medan dari pelaksanaan perjanjian kerjasama BOT terhadap sisi barat lapangan merdeka adalah mendapat bayaran berupa royalti dari pihak investor (bagi hasil dari pengelolaan objek BOT), dan bangunan yang dibangun serta dikelola investor pada akhir masa perjanjian akan menjadi milik pihak Pemko Medan. Saat ini Tanggung jawab pada pelaksanaan perjanjian kerjasama BOT pada Pemko Medan barada di bawah kewenangan Unit Kerja Pengelola Asset atau BPKAD Pemko Medan (Ima Oktorina dalam Cut Zalikha, Skripsi, Fakultas Hukum, Universitas Muhammadiyah Sumatera Utara, 2019). Sedangkan keuntungan yang peroleh PT. OIM adalah laba dari pengoperasioan Merdeka Walk selama kurun waktu masa perjanjian (20 Tahun).

Secara umum Anita kamilah merangkum beberapa keuntungan yang dihasilkan dalam penerapan prinsip kerjasama dengan pola BOT, sebagai berikut: (Anita Kamilah, 2013, h. 166- 
Jurnal Ilmu Hukum

FAKULTAS HUKUM UMSU
Perjanjian BOT...(Rahmat Ramadhani, Ramlan)

Volume 4 Nomor 2, Juli-Desember 2019, 255-270

DOI: https://doi.org/10.30596/dll.v4i2.3182

167).

a. Dari sudut pemerintah:

1) Pemerintah dapat mengurangi penggunaan dana APBN/APBD dan mengurangin jumlah dana pinjaman dari pihak ketiga;

2) Pembiayaan dengan sistem BOT akan menguntungkan secara financial maupun secara administratif, yaitu pemerintah tidak harus mengadakan studi kelayakan, proyek akan dibiayai dan dilaksanakan oleh dan atas resiko pihak lain dan dari mutu atau kualitas hasil pembangunan dapat dipertanggung-jawabkan;

3) Pada akhir masa pengelolaan, maka segala bangunan dan fasilitas yang ada diserahkan kepada pemerintah, dan untuk menjaga agar bangunan beserta fasilitas pendukung yang diserahkan kepada pemerintah tersebut tetap dalam kondisi yang baik, pemerintah tetap membebani kewajiban kepada pihak investor untuk melakukan pemeliharaan maupun perbaikan-perbaikan selama masa BOT tersebut berlangsung;

4) Pemerintah dapat merealisasikan pengadaan infrastruktur yang sangat bermanfaat bagi pelayanan terhadap masyarakat, tanpa mengeluarkan pendanaan yang berarti karna semua ditanggung oleh kontraktor, dan bahkan membuka kesempatan kerja untuk mengurangi jumlah pengangguran;

5) Pembiayaan pembangunan dengan sistem BOT tidak menimbulkan beban utang bagi pemerintah.

b. Dari sudut investor

1) Bagi investor, dengan adanya BOT umumnya investor mendapatkan kesempatan untuk mengambil bagian dalam penanganan dan pengoprasian proyek yang potensial mendatangkan keuntungan yang biasanya selama ini dimonopoli oleh pemerintah sendiri;

2) Memperluas usaha kebidang lain yang mempunyai prospek bagus dan menguntungkan;

3) Menciptakan bidang dan iklim usaha baru;

4) Dapat memanfaatkan lahan strategis yang dimiliki pemerintah.

Dalam perspektif bisnis, selain margin keuntungan tentu diperhitungkan juga tingkat resiko kerugiannya. Dalam penerapan bisnis dengan prinsip BOT terdapat beberapa kemungkinan kerugian yang muncul bagi kedua belak pihak, sebagai berikut: (Anita Kamilah, 2013, h. 166-167).

a. Dari sudut pemerintah

1) Bagi pemerintah adanya proyek BOT ini berarti melepaskan hak monopoli atau hak eksklusif di bidang tertentu dan menyerahkan pada swasta;

2) Melepaskan salah satu sumber pendapatan potensial yang mendatangkan keuntungan, melepaskan hak pengelolaan asset strategis dan memberikannya pada swasta untuk jangka waktu tertentu;

3) Dalam beberapa hal kepada pemerintah diminta untuk melaksanakan dan menyelesaikan masalah yang rumit dan rawan misalnya sehubung dengan acara pembebasan tanah atau lahan.

b. Dari sudut investor 
Jurnal Ilmu Hukum

FAKULTAS HUKUM UMSU
Perjanjian BOT...(Rahmat Ramadhani, Ramlan)

Volume 4 Nomor 2, Juli-Desember 2019, 255-270

DOI: https://doi.org/10.30596/dll.v4i2.3182

1) Usaha yang dilakukan banyak mengandung resiko, baik resiko politik, resiko hukum, resiko ekonomi, serta pasar, serta resiko keadaan memaksa.

2) Memerlukan perhitungan, pertimbangan. Dan persiapan khusus untuk menerapkan pembiayaan melalui sistem BOT ini;

3) Kemungkinan akan menghadapi kendala yang secara konvensional (jaminan berupa tanah) disyaratkan oleh perbankan sehingga dana yang akan diberikan bank tidak akan diberikan jika tanpa jaminan yang cukup memadai.

4) Sebagai akibat lebih lanjut, investor akan menghadapi kesulitan dalam mendapatkan jaminan perbankan karena menurut penilaian perbankan, proyek tersebut kurang "bankable" untuk dibiayai.

5) Kemungkinan pemerintah tidak mau menanggung resiko selama pelaksanaan proyek dan selama masa konsesi.

\section{KESIMPULAN DAN SARAN Kesimpulan}

Perjanjian antara Pemko Medan dengan Investor dalam Pembangunan dan Pengelolaan Sisi Barat Lapangan Merdeka Medan telah menerapkan prinsip-pinsip perjanjian yang berpola BOT. karakteristik perjanjian kerjasamanya memenuhi unsur; membangun, mengelola dan menyerahkan kembali tanah beserta hasil pembangunan yang menjadi kewajiban investor kepada pemko medan berdasarkan kurun waktu perjanjian selama 20 (dua puluh) tahun lamanya masa konsensi.Terakait dengan perjanjian kerjasama antara Pemko Medan dengan Investor dalam Pembangunan dan Pengelolaan Sisi Barat Lapangan Merdeka Medan dengan pola BOT terdapat dua pandangan huku; Pertama, dalam pandangan Hukum Administrasi Negara memandang bahwa kedudukan Pemko Medan dengan Investor sebagai mitranya dalam kontrak perjanjian tidak sama. Hal ini disebabkan karena pemerintah memiliki dua peran (double role) yaitu di satu sisi bekerja norma dan prinsip hukum privat, sementara di sisi lain tidak dapat dilepaskan kedudukan pemerintah sebagai subyek hukum publik, sehingga menjadikan Pemko Medan memiliki kedudukan istimewa dalam hubungan kontraktual dengan inevstor, baik dalam fase pembentukan, fase pelaksanaan, maupun fase pacsa perjanjian. Kedua, dalam pandangan Hukum Bisnis, perjanjian dengan konsep BOT yang telah ditandatangani berpotensi menimbulkan keuntungan dan kerugian bagi kedua belah pihak.

\section{Saran}

Pengunaan dan pemanfaatan lahan Lapangan Merdeka Medan yang merupakan Aset Pemko Medan berupa tanah berdasarkan perjanjian BOT hendaknya kedepan tidak hanya disasarkan pada aspek bisnis saja, tetapi juga dapat dikombinasikan dengan aspek sosial, edukasi, kesehatan dan lain sebagainya dengan kembali mempertimbangkan kepentingan umum masyarakat Kota Medan secara luas serta memperhatikan sisi historis terhadap keberadaan dan fungsi utama Lapangan Merdeka Medan. Pada prakteknya kontrak BOT penggunaan dan pemanfaatan Lapangan Merdeka Medan sebagai Aset Pemko Medan berupa tanah oleh pihak investor akan menimbulkan problematika hukum. Oleh karenanya, sebagai bahan petimbangan untuk menentukan layak tidaknya perpajangan kontrak BOT terhadap 
DEIEGA LATA

Jurnal Ilmu Hukum FAKULTAS HUKUM UMSU
Perjanjian BOT...(Rahmat Ramadhani, Ramlan) Volume 4 Nomor 2, Juli-Desember 2019, 255-270 DOI: https://doi.org/10.30596/dll.v4i2.3182

penggunaan dan pemanfaatan Lapangan Merdeka dimaksud perlu dilakukan kajian mendalam dari berbagai sudut pandang hukum baik dalam lingkup hukum privat maupun hukum publik dalam penentuan model kontak BOT selanjutnya. 
Jurnal Ilmu Hukum

FAKULTAS HUKUM UMSU
Perjanjian BOT...(Rahmat Ramadhani, Ramlan)

Volume 4 Nomor 2, Juli-Desember 2019, 255-270

DOI: https://doi.org/10.30596/dll.v4i2.3182

\section{DAFTAR PUSTAKA}

Info Kota Medan. (2019). Diakses pada tanggal 18 April 2019 melalui http://aamedan.blogspot.co.id/2012/12/profil-kotamedan.html

Kamilah, Anita. (2013). Bangun Guna Serah (Build Operate and Transfer/BOT) Membangun Tanpa Harus Memiliki Tanah (Perspektif Hukum Agraria, Hukum Perjanjian dan Hukum Publik). Bandung: Keni Media.

Korebima, Rachmatia Adonara. (2018). Keabsahan Perjanjian Bangun Serah Yang Dilakukan Pemerintah Provinsi Atas Objek Yang Terletak di Kabupaten Yang Mengalami Pemekaran. DiH Jurnal Ilmu Hukum, Volume 14 Nomor 27, Februari 2018.

Ramadhani, Rahmat. (2018). Konstruksi Hukum Kepemilikan Bangunan Di Atas Tanah Hak Milik Orang Lain Berdasarkan Perjanjian Build Operate and Transfer (BOT). Jurnal EduTech Volume 4 Nomor 1, Maret 2018.

--------. Eksistensi Hak Komunal Masyarakat Hukum Adat Dalam Pengadaan Tanah Untuk Kepetingan Umum. Jurnal Penelitian Hukum DEJURE, Volume 19 No.1, Maret 2019.

Santoso, Budi. (2008). Aspek Hukum Pembiayaan Infrastruktur dengan Model BOT (Build, Operate and Transfer). Yogyakarta: Genta Press.

Setlight, Mercy M. M., dkk. (2013). Karakteristik Perjanjian Bangun Guna Serah. Jurnal Lex et Societatis, Volume I, Nomor 4, Agustus 2013.

Soerodjo, Irawan. (2016). Hukum Perjanjian dan Pertahanan; Perjanjian Build, Operate dan Transfer (BOT) Atas Tanah, Pengaturan, Kararkteristik dan Praktik. Yogyakarta: Laksbang Pressindo.

TIM JDIH BPK Perwakilan Lampung. (2019). Kedudukan Pemerintah dalam Kontrak Build Operate and Transfer (BOT) dengan Pihak Swasta. Diakses padatanggal 19 April 2019 melalui

www.bandarlampung.bpk.go.id/wp.../tulisan_hukum_BOT_Pwk_Lampung_rev.pdf, diakses hari Jum'at, 19 April 2019 Pukul $03 .{ }^{25} \mathrm{WIB}$.

Wacana Penutupan Merdeka Walk, Pengelola: Kami Ikut Pemerintah tapi Hormati Kontrak. Diakses pada tanggal 19 April 2019 melalui tribun-medan.com dengan judul, http://medan.tribunnews.com/2019/02/17/wacana-penutupan-merdeka-walkpengelola-kami-ikut-pemerintah-tapi-hormati-kontrak?page=all

Wirana, Pachta Andjar. (1994). Aspek Hukum Perjanjian Build, Operate and Transfer. Jakarta: Penelitian BPHN.

Zalikha, Cut. (2019). Pelaksanaan Perjanjian Kerjasama Build Operate and Transfer (BOT) dalam Pembangunan dan Pengelolaan Lapangan Merdeka Sebagai Tempat Usaha (Studi di Pemerintahan Kota Medan). (Skripsi, Fakultas Hukum, Universitas Muhammadiyah Sumatera Utara). 